\title{
DAMPAK PERUBAHAN IKLIM TERHADAP KENAIKAN MUKA AIR LAUT DI WILAYAH PESISIR PANGANDARAN
}

\author{
Bambang Dwi Dasanto ${ }^{1}$, Sulistiyanti ${ }^{1, *}$, Anria $^{1}$, Rizaldi Boer ${ }^{1}$ \\ ${ }^{1}$ Centre for Climate Risk and Opportunity Management in Southeast Asia Pasific (CCROM - \\ SEAP) Gedung Fisik dan Botani Lantai 2, Kampus Institut Pertanian Bogor (IPB) Baranangsiang, \\ Bogor 16143 \\ *Email: sulis.ipb46@gmail.com
}

\begin{abstract}
RINGKASAN
Salah satu dampak paling signifikan dari perubahan iklim adalah kenaikan permukaan laut. Wilayah pesisir Pangandaran yang terletak di Selatan Jawa Samudra Hindia secara langsung memiliki risiko banjir lebih tinggi akibat kenaikan permukaan laut (SLR) dibandingkan dengan wilayah pesisir di Utara Jawa. Dampak langsung dari kenaikan muka laut, pada umumnya, diukur berdasarkan besarnya kerusakan fisik maupun kerugian ekonomi. Dalam kajian ini, kerusakan fisik dinotasikan sebagai persentase penyusutan atau perubahan penggunaan/tutupan lahan yang terpapar oleh banjir air laut. Kerugian ekonomi didekati dengan biaya kerusakan tiap jenis penggunaan lahan yang terpapar oleh banjir air laut. Satuan biaya (unit cost) tiap jenis penggunaan/tutupan lahan yang terusakkan dapat diperoleh dari hasil survei kuesioner, diskusi kelompok mendalam (focus group discussion, FGD), dan riset terdahulu. Hasil analisis SLR menunjukkan bahwa sementara penurunan tanah mencapai lebih dari 85 ha. Sementara itu, kerugian permanen akibat SLR pada 2025 dan 2050 hampir sama yaitu sekitar 40 ha, meskipun SLR meningkat lebih dari 0,24 meter menjadi 0,50 meter (skenario rendah) atau dari 0,30 meter hingga 0,64 meter (skenario tinggi). Ini bisa dimengerti karena elevasi Pantai Pangandaran cukup tinggi. Selain kerugian fisik, jenis kerugian lain yang disebabkan oleh SLR rusak atau hilang sebagian dari penggunaan lahan. Hasil analisis menunjukkan bahwa kerugian tertinggi terjadi di sektor permukiman dibandingkan dengan sektor pertanian, dan permukiman yang terkena dampak SLR lebih luas dengan meningkatnya periode proyeksi
\end{abstract}

Kata kunci : Perubahan Iklim, Kenaikan Muka Air Laut, Dampak, Kerugian

\section{PERNYATAAN KUNCI}

Perubahan iklim merupakan isu lingkungan yang banyak dibicarakan oleh berbagai kalangan hingga skala global. Hal ini disebabkan perubahan iklim dapat berdampak negatif terhadap berbagai sektor kehidupan, termasuk kehidupan masyarakat di wilayah pesisir.

Kenaikan muka air laut merupakan kejadian yang telah terjadi berabad-abad yang lalu. Namun di era modern perkembangan dan pertumbuhan di wilayah 
pesisir yang tinggi baik itu populasi yang semakin padat, pembangunan ekonomi pesisir yang tinggi, infrastruktur vital, mengakibatkan kenaikan muka air laut menjadi bencana yang perlu diwaspadai.

Dampak kenaikan muka air laut yang sangat merugikan bagi wilayah pesisir mendorong banyak studi untuk memprediksi kejadian dan kerugian yang diakibatkan oleh kenaikan muka air laut. Dampak dari kenaikan muka air laut akan bervariasi tergantung lokasi, karakter biofisik dan factor sosioekonomi termasuk respon manusia yang tinggal di wilayah tersebut. Dampak utama dari kenaikan muka air laut adalah perubahan fisik lingkungan.

\section{REKOMENDASI KEBIJAKAN}

Pengarusutamaan isu adaptasi perubahan iklim, khususnya terkait penanganan dampak kenaikan muka air laut perlu dilaksanakan agar tercapai program dan kegiatan pembangunan daerah yang tangguh iklim. Sinergi, koordinasi, dan komunikasi semua pihak mulai dari stakeholder hingga masyarakat menjadi penting dalam mewujudkan upaya adaptasi yang baik dan terintegrasi antar sektor dan antar wilayah.

Perlu adanya ketegasan dan peraturan yang ketat dari pemerintah daerah mengenai pengendalian pemanfaatan lahan pesisir dan standar bangunan di kawasan pesisir.
Peningkatan kapasitas dan keterlibatan masyarakat setempat dalam menjaga dan melestarikan lingkungan pesisir.

\section{PENDAHULUAN}

Isu perubahan iklim akibat pemanasan global telah menjadi perhatian utama dunia, karena ia berdampak besar pada kehidupan manusia. Seiring dengan semakin intensnya pemanasan global, kejadian bencana yang berkaitan dengan iklim, akan semakin sering terjadi dengan intensitas yang semakin tinggi. Pada tahun 1997/1998 Indonesia mengalami kekeringan ekstrim akibat El Nino dan pada tahun 1999 curah hujan diatas normal terjadi akibat La Nina. Selain itu kenaikan muka air laut setinggi $20 \mathrm{~cm}$ hingga $30 \mathrm{~cm}$ akan menyebabkan kejadian banjir di sebagian besar wilayah Indonesia khususnya di wilayah pesisir.

Kabupaten Pangandaran berlokasi di pantai selatan Jawa dengan kerentanan yang cukup tinggi terhadap masalah banjir rob/ kenaikan muka air laut dan intrusi air laut. Pesisir ini baru mengalami ancaman ketika terkena perubahan muka laut yang relatif tinggi (seperti tsunami). Menurut analisis kenaikan muka air laut dan proyeksi ICCSR (2010), kenaikan muka air laut di wilayah selatan Jawa berkisar antara $0.2 \mathrm{~cm}$ hingga $0.4 \mathrm{~cm}$ per tahun. Kenaikan muka air laut pada tahun 2030 akan mencapai $6 \mathrm{~cm}$ hingga $30 \mathrm{~cm}$ di kawasan Indonesia. Pada 
tahun 2050, kenaikan muka air laut mencapai $10 \mathrm{~cm}$ hingga $50 \mathrm{~cm}$ sedangkan pada tahun 2080 akan mencapai $16 \mathrm{~cm}$ hingga $80 \mathrm{~cm}$. Menurut IPCC WG II (2011) isu kenaikan muka air laut menjadi salah satu pembahasan utama perubahan iklim karena berdampak sangat besar pada ekonomi. Wilayah pesisir Pangandaran mempunyai peruntukan fungsi lahan yang beranekaragam, mulai dari lokasi tempat tinggal, perkebunan, perdagangan, wisata, industri dan berbagai sektor lainnya. Wilayah tersebut merupakan wilayah yang sangat potensial untuk perkembangan ekonomi, namun sangat rentan tehadap kenaikan muka air laut. Kenaikan muka air laut setinggi $60 \mathrm{~cm}$ akan menyebabkan Indonesia kehilangan $34.000 \quad \mathrm{~km}^{2}$ wilayahnya dan mengancam kehidupan 2 juta penduduk.

Berdasarkan tingginya kerugian yang diakibatkan oleh perubahan muka laut di pesisir Pangandaran (termasuk dalam hal ini adalah pasang tinggi dan tsunami) maka kajian ini menjadi penting untuk dilakukan. Selain itu, perubahan iklim yang diakibatkan oleh peningkatan suhu global telah menyebabkan memuainya air laut dan ini menyebabkan muka laut global naik sekitar $0.09-0.88 \mathrm{~m}$ dengan laju sekitar 4.9 $\mathrm{mm} /$ tahun (IPCC, 2001). Trend kenaikan ini sejalan dengan hasil analisa data observasi periode 1961-2003, yaitu 1.8 $\mathrm{mm} /$ tahun, sedangkan pada periode data
1993-2003 laju kenaikannya lebih tinggi yaitu $3.1 \mathrm{~mm} /$ tahun (IPCC, 2007). Dampak dari naiknya muka laut ini adalah hilangnya lahan (land loss) yang akan diikuti oleh kerugian baik fisik maupun ekonomi di wilayah itu. Tujuan dari kajian ini adalah: (i) mengidentifikasi, memprediksi dan memetakan genangan air laut di wilayah pesisir Kabupaten Pangandaran yang disebabkan oleh SLR, dan (ii) meneliti dampak SLR pada sektor fisik dan sosialekonomi. Hasil kajian ini diharapkan dapat (i) menjadi referensi dan informasi dasar untuk mengembangkan wilayah pesisir yang tangguh dalam menghadapi risiko perubahan iklim di masa depan, khususnya yang terkait dengan SLR, dan (ii) menjadi dasar referensi untuk mengurangi risiko kerusakan dari bencana alam yang dipicu oleh SLR.

\section{METODOLOGI}

Penilaian dampak perubahan iklim dan SLR untuk wilayah pesisir Pangandaran terdiri dari beberapa tahap. Pertama, identifikasi terhadap perubahan muka laut rata-rata global maupun variasi spasial regional dan/atau lokal. Kedua, pemetaan wilayah yang berpotensi terpapar oleh SLR. Terakhir adalah menganalisis potensi kerugian (fisik dan ekonomi) yang diakibatkan oleh SLR. 


\section{Data}

Jenis data yang digunakan dalam kajian ini berupa data primer dan sekunder.

Data primer didapat dari wawancara responden penduduk setempat, dengan kuisioner. Data sekunder didapat dari berbagai sumber data yang relevan berupa buku referensi, jurnal, web, serta informasi dan sumber dari instansi terkait Badan Informasi Geospasial (BIG), dan Badan Meteorologi Klimatologi dan Geofisika (BMKG). Terkait kebutuhan analisis dampak perubahan iklim dan kenaikan muka laut untuk wilayah pesisir digunakan dua jenis data, yaitu data atribut dan data analog. Data atribut terdiri dari data perubahan muka laut global dan regional, pasang-surut air laut, debit sungai, data hujan historis dan masa depan, dan informasi kejadian banjir di wilayah pesisir.

Perubahan muka laut rata-rata global merupakan perubahan volume laut secara global. Perubahan ini disebabkan oleh pemuaian air laut (thermal expansion of the oceans) karena meningkatnya suhu global, mencairnya gletser dan lapisan es, serta berubahnya keseimbangan massa es di Greenland dan Antartika (Bindoff et al., (2007); Shepherd dan Wingham (2007) dalam Nicholls et al., 2011). Dalam kajian ini, perubahan muka laut global diduga menggunakan perangkat lunak SimCLIM 2013. Hasil analisis SimCLIM berupa proyeksi kenaikan muka laut global berdasarkan empat skenario Representative Concentration Pathways (RCPs), yaitu RCP2.6, RCP4.5, RCP6.0 dan RCP8.5 (Yin et al., 2013).

Perubahan muka laut regional diperoleh berdasarkan hasil analisis data SODA dan satelit altimetri. SODA merupakan seperangkat data re-analysis yang terdiri dari beberapa variabel lautan global dalam bentuk grid dan salah satunya adalah muka laut rata-rata (Carton et al., 2005).

Data pasang air laut harian untuk periode 1985-2015 diperoleh dari Badan Informasi Geospasial (BIG). Debit sungai didapat dari Balai Besar Wilayah Sungai (BBWS) Citanduy. Hujan historis diekstrak dari CHIRPS v2.0, sedangkan hujan masa depan dibangkitkan dari model iklim RegCM4 yang memiliki resolusi horisontal $20 \mathrm{~km}$ dan di-run di bawah kondisi skenario emisi RCP 4.5. Sementara itu, informasi kejadian banjir di wilayah pesisir diperoleh melalui proses Focus Group Discussion (FGD). Selanjutnya, data spasial yang digunakan dalam kajian ini terdiri dari peta topografi, data Model Elevasi Digital (DEM) SRTM, dan peta penggunaan/tutupan lahan dari Badan Planologi Kementerian Kehutanan tahun 2013.

\section{Pendugaan Daerah Sasaran Banjir Akibat Perubahan Muka Laut}

Dalam kajian ini, data dasar yang digunakan terdiri dari data topografi, 
penggunaan lahan, dan data elevasi digital sedangkan alat bantu analisis berupa perangkat lunak Sistem Informasi Geografi (GIS). Topografi digital berguna untuk membatasi wilayah studi sedangkan data penggunaan lahan digital untuk mengidentifikasi jenis-jenis penggunaan lahan yang berpotensi terpapar oleh kenaikan tinggi muka laut. Sementara itu, data elevasi digital diekstrak dari data DEM SRTM yang beresolusi horisontal $30 \mathrm{~m}$ dan vertikal sekitar $1 \mathrm{~m}$. Sebaran daerah sasaran banjir untuk tiap perubahan tinggi muka laut dianalisis dengan perangkat lunak GIS dengan komponen data input berupa data DEM dan penggunaan lahan digital

\section{Penilaian Dampak Kenaikan Muka Air Laut}

Penilaian dampak yang diterapkan dalam kajian ini menggunakan pendekatan dampak standar. Pendekatan ini bersifat topdown; alasannya, pendekatan ini mengkombinasikan berbagai skenario yang di-downscale dari model iklim global ke lokal; urutan tahapan analitis bermula dari sistem iklim kemudian bergerak ke dampak biofisik dan selanjutnya ke penilaian sosio-ekonomi (Carter et al., 1994 dalam Nicholls et al., 2011).

Tahap awal dari penilaian dampak fisik dan ekonomi akibat kenaikan muka laut adalah menilai potensi kerusakan dan/atau kehilangan lahan akibat kenaikan muka laut. Dalam kasus ini, pendekatan yang dapat digunakan adalah cross map, sedangkan teknik yang digunakan adalah tumpangsusun (overlay) antara peta penggunaan lahan dan peta daerah sasaran banjir akibat kenaikan muka laut untuk wilayah studi.

Dalam penilaian tingkat kerugian banjir pada permukiman dan pertanian dilakukan menggunakan model matematik sederhana. Model ini dibangun dengan menggunakan data hasil survei lapang. Hasil model tersebut dapat digunakan untuk menilai kerugian banjir pada tiap satuan wilayah analisa banjir.

Pada studi ini masukan (input) yang digunakan sebagai bahan penilaian dampak fisik dan ekonomi akibat kenaikan muka laut yaitu distribusi dan persen potensi luas lahan tergenang periodik (degradation land) dan permanen (land loss) serta kelas kerugian banjir akibat kenaikan muka laut. Distribusi dan persen potensi luas lahan tergenang periodik dan permanen. Tumpang susun antara peta penggunaan/penutupan lahan dan peta daerah sasaran banjir akibat kenaikan muka laut akan menghasilkan informasi potensi lahan tergenang periodik dan permanen. Melalui evaluasi potensi penyusunan lahan maka didapatkan distribusi dan persen potensi luas lahan tergenang periodik dan permanen.

Kerugian banjir akibat kenaikan muka laut diestimasi untuk dua jenis kerugian yaitu kerugian sektor pemukiman dan 
sektor pertanian. Obyek sasaran banjir pada sektor pemukiman dibagi menjadi tiga bagian, yaitu: (i) bangunan, (ii) isi bangunan, dan (iii) pembersihan sisa bangunan. Tingkat kerugian banjir pada ketiga obyek tersebut sangat dipengaruhi oleh kedalaman genangan banjir, luas banjir dan kualitas bangunan permukiman yang menjadi sasaran banjir. Tahap awal estimasi adalah dengan menumpang susunkan antara peta ketinggian wilayah dan peta daerah sasaran banjir akibat Kenaikan Muka Laut. Hasil dari tumpang susun tersebut berupa peta kedalaman genangan banjir akibat kenaikan muka laut (periodik dan permanen).

Data hasil survei kuisioner digunakan untuk pengembangan fungsi matematik; dan, hasilnya digunakan untuk menilai kerugian banjir. Dari data kuisioner dibuat fungsi kedalaman-kerugian banjir akibat kenaikan muka laut untuk sektor pemukiman $\mathrm{f}(\mathrm{D}-\mathrm{K})$, sedangkan untuk sektor pertanian dibuat fungsi lamakerugian banjir akibat kenaikan muka laut $\mathrm{f}(\mathrm{L}-\mathrm{K})$. Bentuk umum dari fungsi kedalaman-kerugian banjir sektor pemukiman adalah $y=f(x)+\varepsilon$, di mana kerugian banjir merupakan respon (peubah y), sedangkan kedalaman genangan banjir adalah penjelas (peubah $\mathrm{x}$ ); artinya, setiap peningkatan kedalaman genangan banjir sebesar satu satuan akan memberikan respon terhadap kerugian banjir sebesar satu satuan.
Kerugian pada sektor permukiman. Berdasarkan obyek permukiman yang menjadi sasaran banjir, ada 3 fungsi yang dapat dibentuk dan ini dinotasikan sebagai CsPn, $C i P n$, dan $C p P n$ di mana masingmasing merepresentasikan fungsi kedalaman dan kerugian banjir pada bangunan permukiman, isi bangunan permukiman, dan pembersihan sisa banjir. Fungsi $C s P n, C i P n$, dan $C p P n$ secara umum dinotasikan sebagai f(D-K). Selanjutnya, bentuk umum dari persamaan kerugian banjir pada sector permukiman dapat didefinisikan sebagai berikut:

$$
K P_{k} U_{i}=P_{k} \times D \times f(D-K)
$$

di mana $K P_{k} U_{i}$ adalah kerugian pada pemukiman untuk kategori ke-k dan unit analisa ke-i (Rp.); P adalah pemukiman (jumlah KK yang terkena dampak per desa); $\mathrm{f}(\mathrm{D}-\mathrm{K})$ adalah fungsi kedalaman-kerugian banjir (Rp./rumah), D adalah kedalaman banjir dan i adalah unit berisikan informasi nama desa, penggunaan lahan, periode ulang banjir dan kedalaman genangan banjir.

Kerugian pada sektor pertanian. Bentuk umum dari persamaan kerugian banjir pada sektor pertanian adalah:

$\mathrm{K}=$ Luas Sawah (desa) $\mathrm{x}$ kedalaman SLR $\mathrm{x}$ $\mathrm{f}(\mathrm{D}-\mathrm{K})$

dimana $\mathrm{K}$ adalah kerugian pemukiman, luas sawah merupakan proporsi luasan sawah yang tergenang SLR terhadap luasan total sawah, kedalaman SLR adalah kedalaman 
genangan rata-rata yang terjadi di sawah untuk masing-masing periode ulang $\operatorname{dan} f(D$ - K) adalah fungsi kedalaman-kerugian banjir (Rp/ha).

\section{SITUASI/ HASIL}

Pangandaran dapat diklasifikasikan menjadi 4 kelas topografi, yaitu berbukit, berombak, bergelombang dan datar. Topografi datar terletak di bagian selatan dengan elevasi kurang dari $25 \mathrm{~m}$ dpal. Berdasarkan kondisi topografinya, wilayah bertopografi datar adalah wilayah yang rentan terhadap SLR. Dampak dari SLR adalah berkurangnya luas lahan pesisir dan naiknya kerugian sosial-ekonomi.

Topografi datar di wilayah ini menyebar dari Kecamatan Cijulang, Parigi, Sidamulih dan Pangandaran dengan elevasi bervariasi antara 8-25 $\mathrm{m}$ dpal dan kurang dari $8 \mathrm{~m}$ dpal. Wilayah pesisir dengan elevasi kurang dari $8 \mathrm{~m}$ dpal terdapat di sebagian Kecamatan Parigi dan Cijulang dan pesisir di dua kecamatan ini lebih rentan terhadap SLR daripada pesisir di Kecamatan Sidamulih dan Pangandaran.

\section{Kenaikan Muka Air Laut}

Tabel 1. SLR rata-rata global di sekitar pesisir Pangandaran pada tahun proyeksi 2025-2100 berdasarkan model SimCLIM 2013 dengan skenario emisi RCP4.5

\begin{tabular}{lrrr}
\hline \multirow{2}{*}{ Tahun } & \multicolumn{3}{c}{ Skenario SLR rata-rata global $(m)$} \\
2025 & Rendah $($ Low $)$ & Sedang $($ Mid $)$ & Tinggi $($ High $)$ \\
\cline { 2 - 4 } 2050 & 0.136 & 0.159 & 0.194 \\
2075 & 0.295 & 0.365 & 0.434 \\
2100 & 0.466 & 0.594 & 0.721 \\
\hline
\end{tabular}


Dalam kajian ini perubahan tinggi muka laut regional diasumsikan mengikuti tren dari data satelit altimetri. Berdasarkan data tren tersebut, perubahan tinggi muka laut regional dapat diproyeksikan hingga tahun 2100 atau selama abad 21. Seperti ditunjukkan pada Tabel 2. perubahan tinggi muka laut untuk wilayah pesisir Pangandaran terjadi secara bertahap. Pada tahun 2025 dan 2050, tinggi muka laut diperkirakan naik 0.107 dan $0.214 \mathrm{~m}$; namun, pada tahun 2075 dan 2100, tinggi muka laut diperkirakan naik lebih tinggi lagi yaitu 0.321 dan $0.427 \mathrm{~m}$. Artinya, SLR regional pada akhir abad 21 diperkirakan dapat mencapai sekitar $0.427 \mathrm{~m}$ atau hampir mencapai 0.50 meter.

Tabel 2. Tinggi muka laut di wilayah pesisir Pangandaran berdasarkan hasil analisis tren menggunakan data satelit altimetri

\begin{tabular}{ccc}
\hline \multicolumn{3}{c}{ Tren tinggi muka laut (meter) pada tahun proyeksi } \\
\hline 2025 & 2050 & 2100 \\
0.107 & 0.214 & 0.427 \\
\hline
\end{tabular}

Selanjutnya, seperti yang telah disampaikan di awal bahwa SLR relatif dipengaruhi oleh komponen SLR global dan perubahan muka laut regional; dan, ini telah diringkas dalam Tabel 1 dan 2. Tabel 3. Skenario SLR relatif di pesisir Pangandaran

\begin{tabular}{lcc}
\hline \multirow{2}{*}{ Tahun proyeksi } & \multicolumn{2}{c}{ Skenario SLR relatif (meter dpal) } \\
\cline { 2 - 3 } 2025 & Rendah (Low) & Tinggi (High) \\
\cline { 2 - 3 } 2050 & 0.243 & 0.301 \\
2075 & 0.509 & 0.648 \\
2100 & 0.787 & 1.042 \\
& 1.052 & 1.459 \\
\hline
\end{tabular}

Berdasarkan Tabel 3 SLR relatif pada tahun proyeksi 2050 untuk skenario rendah (low) adalah sekitar $0.51 \mathrm{~m}$ dpal. Namun, pada skenario tinggi (bigh) SLR relatif di lokasi kajian dapat mencapai sekitar $0.65 \mathrm{~m}$ dpal. Interpretasi terhadap tabel yang sama, SLR relatif pada tahun 2100 meningkat tajam, yaitu sekitar $1.10 \mathrm{~m}$ dpal pada skenario rendah sedangkan pada skenario
Kombinasi terhadap dua komponen utama tersebut dapat dilihat pada Tabel 3 yang mencerminkan SLR relatif di pesisir Pangandaran. 
sedangkan yang lainnya diklasifikasikan dalam dampak ekonomi.

\section{Dampak Fisik Akibat SLR}

$$
\text { Seperti telah diungkapkan }
$$

sebelumnya bahwa pesisir dengan topografi datar dengan elevasi kurang dari $8 \mathrm{~m}$ dpal merupakan pesisir yang rentan terhadap SLR. Salah-satu bentuk dampak fisik dari SLR adalah terendamnya lahan secara permanen dan sementara (periodik). Lahan yang terendam secara permanen dikategorikan sebagai penyusutan atau pengurangan luas lahan (land loss), sedangkan yang terendam secara periodik dikategorikan sebagai lahan terdegradasi.

\section{A. Potensi Daerah Genangan Banjir Periodik dan Permanen}

Berdasarkan hasil model SLR, potensi luas lahan terendam secara periodik di lokasi studi mencapai lebih dari 85 ha (lihat Tabel 4) dan ini terjadi rata-rata sekali dalam rentang waktu 100 tahun. Lahan yang terendam air laut secara periodik akan mengalami penurunan kualitas; hasilnya berupa lahan terdegradasi. Distribusi dari lahan terdegradasi tersebut terdapat di beberapa desa, yaitu: desa Batukaras (Kec. Cijulang), desa Karangjaladri (Kec. Parigi), desa Cikembulan, Sukaresik (Kec. Sidamulih), desa Legokjawa, Masawah (Kec. Cimerak), desa Pamotan, Putrapinggan (Kec. Kalipucang), dan desa Pangandaran, Babakan, (Kec. Pangandaran). Menurut persentasenya, luas lahan terdegradasi dengan persentase tertinggi terdapat di desa Sukaresik (29.39\%).

Tabel 4. Potensi luas genangan banjir periodik (sementara) akibat pasang tinggi untuk periode ulang $1,5,25,50$, dan 100 tahun

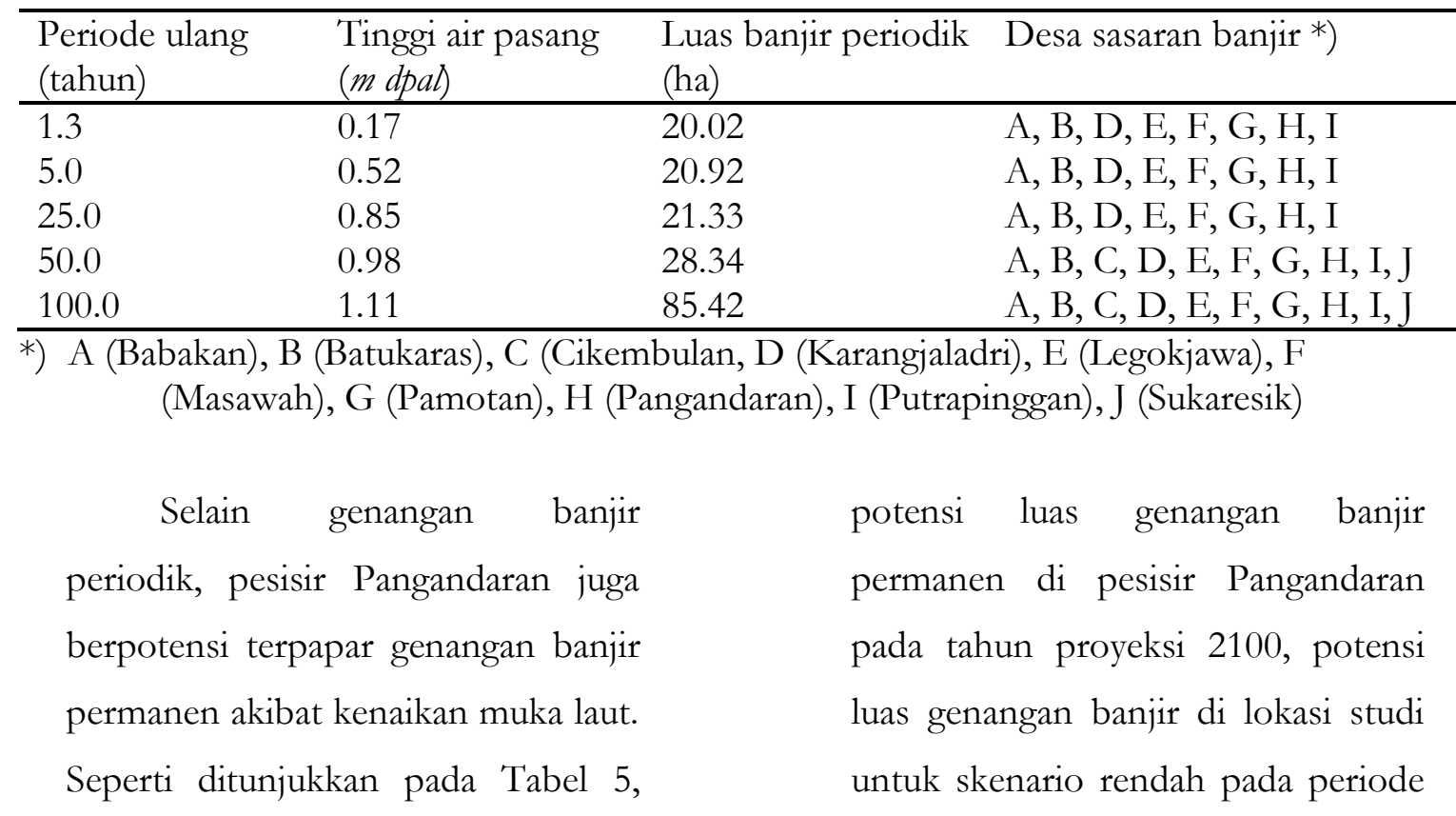


ulang 1 tahun diduga mencapai sekitar 85.48 ha sementara itu, pada periode ulang 5 tahun dapat mencapai 85.80 ha. Persentase perubahan luas genangan permanen pada dua periode ulang yang berbeda ini mencapai sekitar $0.37 \%$. Pada tahun proyeksi yang sama tetapi untuk skenario tinggi, potensi luas genangan banjir pada periode ulang 1 tahun mencapai sekitar 85.86 ha. Namun, pada periode ulang 5 tahun luas genangannya mencapai sekitar 135.11 ha. Ini berarti terjadi perubahan luas genangan permanen sebesar $57.36 \%$. Berdasarkan hasil analisis ini, perbedaan skenario kenaikan muka laut rendah ke tinggi untuk tahun proyeksi 2100 menunjukkan pengaruh yang sangat signifikan terhadap perubahan luas genangan permanen di pesisir Pangandaran.

Tabel 5. Potensi luas genangan banjir permanen berdasarkan skenario kenaikan muka laut relatif (rendah dan tinggi) untuk periode ulang 1, 5, 25, 50, dan 100 tahun. Genangan permanen diskenariokan terjadi pada tahun proyeksi 2050 dan 2100

\begin{tabular}{|c|c|c|c|c|}
\hline \multirow{3}{*}{$\begin{array}{l}\text { Periode ulang } \\
\text { kejadian (tahun) }\end{array}$} & \multicolumn{4}{|c|}{ Potensi luas genangan banjir permanen (ha) } \\
\hline & \multicolumn{2}{|c|}{ Skenario rendah (low) } & \multicolumn{2}{|c|}{ Skenario tinggi (bigh) } \\
\hline & 2050 & 2100 & 2050 & 2100 \\
\hline 1 & 21.33 & 85.48 & 21.34 & 85.86 \\
\hline 5 & 85.24 & 85.80 & 85.64 & 135.11 \\
\hline 25 & 85.53 & 88.33 & 85.73 & 154.22 \\
\hline 50 & 85.59 & 149.60 & 85.86 & 154.42 \\
\hline 100 & 85.86 & 153.31 & 85.92 & 154.45 \\
\hline
\end{tabular}

B. Potensi Kehilangan Lahan (Land Loss) Akibat SLR

Beberapa kajian telah membuktikan bahwa perubahan iklim dan SLR akan berdampak serius pada lingkungan dan penduduk yang tinggal di zona pesisir Snoussi et al.. (2008). Khusus wilayah pesisir Pangandaran, SLR diprediksi akan menyebabkan hilangnya sebagian lahan (land loss) di wilayah itu.
Tumpang-susun antara peta skenario genangan akibat SLR dan peta penggunaan/tutupan lahan menghasilkan potensi luas lahan yang hilang seperti dilihat pada Tabel 6 . Berdasarkan hasil analisis tersebut, potensi kehilangan tertinggi akan terjadi pada permukiman di sekitar pesisir, diikuti oleh pertanian lahan kering dan pertanian lahan kering campur.

Tabel 6. Penggunaan/tutupan lahan yang hilang akibat SLR 


\begin{tabular}{lrrrrrrrr}
\hline Penggunaan/Tutupan & \multicolumn{6}{c}{ Luas Kehilangan Lahan(Ha) Akibat SLR } \\
\cline { 2 - 10 } & \multicolumn{7}{c}{ Skenario Rendah } & \multicolumn{5}{c}{ Skenario Tinggi } \\
\cline { 2 - 10 } & 2025 & 2050 & 2075 & 2100 & 2025 & 2050 & 2075 & 2100 \\
\hline Belukar & 5.2 & 5.2 & 5.2 & 5.2 & 5.2 & 5.2 & 5.2 & 5.2 \\
\hline $\begin{array}{l}\text { Hutan Lahan Kering } \\
\text { Sekunder }\end{array}$ & 0.3 & 0.3 & 0.3 & 0.3 & 0.3 & 0.3 & 0.3 & 0.3 \\
\hline $\begin{array}{l}\text { Hutan Mangrove } \\
\text { Sekunder }\end{array}$ & 3.4 & 3.4 & 3.4 & 3.4 & 3.4 & 3.4 & 3.4 & 3.4 \\
\hline Pemukiman & 10.3 & 10.3 & 10.3 & 31.5 & 10.3 & 10.3 & 31.5 & 31.9 \\
\hline $\begin{array}{l}\text { Pertanian Lahan } \\
\text { Kering }\end{array}$ & 9.1 & 9.1 & 9.1 & 14.2 & 9.1 & 9.1 & 14.1 & 14.4 \\
\hline $\begin{array}{l}\text { Pertanian Lahan } \\
\text { Kering Campur }\end{array}$ & 7.7 & 8.1 & 8.5 & 9.4 & 8.0 & 8.1 & 9.4 & 9.4 \\
\hline Tanah Kosong & 5.7 & 5.8 & 5.8 & 16.0 & 5.7 & 5.8 & 16.0 & 16.0 \\
\hline Badan Air & 0.0 & 0.0 & 0.0 & 25.8 & 0.0 & 0.0 & 25.9 & 25.8 \\
\hline \multicolumn{1}{c}{ Total Kehilangan } & 41.7 & 42.1 & 42.5 & 105. & 42.0 & 42.1 & 105.8 & 106. \\
\multicolumn{1}{c}{ Lahan } & & & & 8 & & & & 4 \\
\hline
\end{tabular}

\section{Kerugian Akibat $S L R$}

Selain kerugian fisik, jenis kerugian lain yang perlu diidentifikasi sebagai akibat SLR adalah rusak atau hilangnya sebagian penggunaan lahan. Dalam kajian ini, analisis kerugian hanya dilakukan pada sektor permukiman dan pertanian. Dalam kajian ini dampak negatif dinyatakan dengan luas penggunaan lahan yang terpapar SLR dan besarnya nilai kerugian yang ditimbulkannya.

Perkiraan kerugian pada sektor pemukiman dihitung berdasarkan fungsi kedalaman-kerugian yang didapat dari hasil survei kuisioner. Sedangkan untuk menghitung kerugian yang diderita oleh sektor pertanian dibuat hubungan antara kerugian dan kedalaman banjir.

Hasil analisis kerugian untuk sektor pemukiman dan pertanian di Kabupaten Pangandaran dapat dilihat pada Gambar 6. Seperti ditunjukkan pada gambar tersebut, total kerugian paling tinggi adalah kerugian pada sektor permukiman. Artinya, luas penggunaan lahan permukiman yang terdampak oleh SLR semakin luas untuk setiap penambahan tahun proyeksi. 


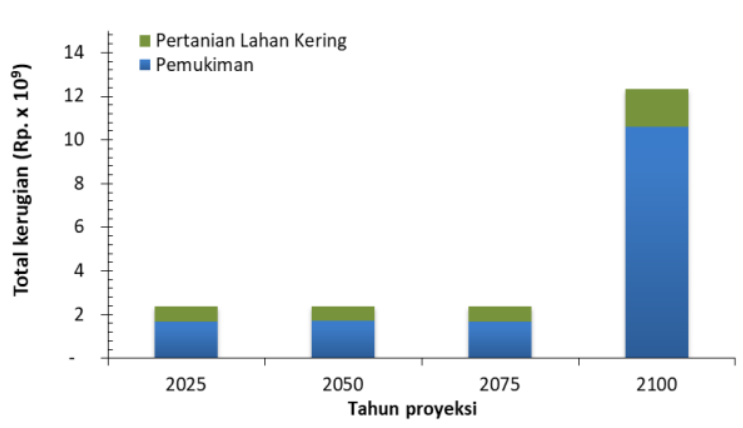

(a1

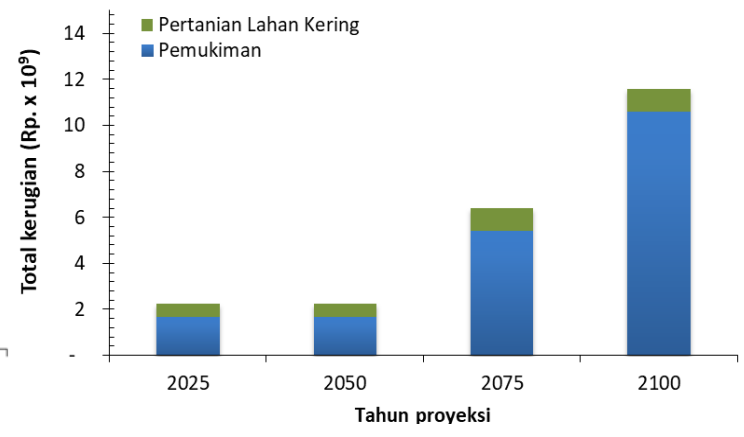

(a2)

Gambar 6. Kerugian pengggunaan lahan akibat SLR Kabupaten Pangandaran di bawah skenario rendah (a1) dan di bawah scenario tinggi (a2)

\section{ANALISIS DAN ALTERNATIF SOLUSI/ PENANGANAN}

Salah-satu bentuk dampak fisik dari SLR adalah terendamnya lahan secara permanen dan sementara (periodik). Hasil analisis SLR menunjukkan bahwa potensi luas lahan terendam secara periodik mencapai lebih dari 85 ha, dan ini terjadi rata-rata sekali dalam rentang waktu 100 tahun. Lahan yang terendam air laut secara periodik akan mengalami penurunan kualitas; hasilnya berupa lahan terdegradasi. Menurut persentasenya, luas lahan terdegradasi dengan persentase tertinggi terdapat di Desa Sukaresik (29.39\%). Berdasarkan bentuk topografinya, desa Sukaresik masuk dalam kategori topografi datar hingga cekung dan elevasinya kurang dari $1 \mathrm{~m}$ dpal. Artinya, pada saat tinggi pasang mencapai lebih dari $1 \mathrm{~m}$ dpal (periode ulang 100 tahun) maka desa-desa dengan elevasi kurang dari $1 \mathrm{~m}$ dpal akan terendam meskipun sifatnya sementara.
Kondisi ini menunjukkan bahwa desa Sukaresik harus diprioritaskan dalam kaitannya penanganan dampak SLR. Sehubungan dengan hal ini kebijakan Pemerintah Daerah sangat berperan penting untuk mewujudkan terlaksananya program pengurangan dampak SLR di kawasan pesisir. Salah satu upaya yang dapat dilakukan oleh Pemerintah Daerah adalah dengan memasukkan alokasi dana khusus penanganan kawasan pesisir ke dalam Rencana Pembangunan Jangka Menengah Daerah (RPJMD).

Selain kerugian fisik, jenis kerugian lain yang perlu diidentifikasi sebagai akibat SLR adalah rusak atau hilangnya sebagian penggunaan lahan. Hasil analisis kerugian menunjukkan bahwa kerugian paling tinggi terjadi pada sektor permukiman dibandingkan sektor pertanian. Artinya, luas penggunaan lahan permukiman yang terdampak oleh SLR semakin luas untuk setiap penambahan tahun proyeksi. 
Merujuk pada hal tersebut, maka perlu adanya upaya dalam mengantisipasi dampak naiknya muka air laut, berupa mitigasi dan adaptasi. Upaya mitigasi dan adaptasi dapat dilakukan dengan cara membangun tembok pelindung pantai, meninggikan pondasi bangunan dan jalan, serta betonisasi dinding sungai/pantai.

\section{REFERENSI}

Carton, J., Giese, B.and Grodsky, S. 2005. Sea level rise and the warming of the oceans in the simple ocean data assimilation (soda) ocean reanalysis. J. Geophys. Res, 110. DOI 10.1029/2004JC002817.

IPCC. 2001. Climate Change 2001: The Physical Science Basis. (eds.) J. T. Houghton, Y. Ding, D.J. Griggs, M. Noguer, P. J. van der Linden and D. Xiaosu. Working Group 1 Contribution to the Third Assessment Report of the Intergovernmental Panel on Climate Change (IPCC). Appendix II.3.11 on GHG forcing)Nicholls, R., 2003. Case study on sea-level rise impacts

IPCC. 2007. Intergovernmental Panel on Climate Change. 2007. Climate Change 2007: Mitigation of Climate
Change. Contribution of Working Group III to the Fourth Assessment Report of The Intergovernmental Panel on Climate Change [B. Metz, O.R. Davidson, Bosch P.R., Dave, R., Meyer, L.A. (eds)]. Cambridge University Press, Cambridge, United Kingdom and New York, NY, USA. (http://www.ipcc.ch/pdf/assessm ent-report/ar4/wg3/ar4-wg3chapter9.pdf).

Nicholls, R., Hanson, S., Lowe, J., Warrick, R., Lu, X., Long, A., and Carter, T. 2011. Constructing sea-level scenarios for impact and adaptation assessment of coastal area: A guidance document. In: Supporting Material, Intergovernmental Panel on Climate Change Task Group on Data and Scenario Support for Impact and Climate Analysis.

Snoussi, M., Ouchani, T.and Niazi, S. 2008. Vulnerability assessment of the impact of sea-level rise and flooding on the moroccan coast: The case of the mediterranean eastern zone. Estuarine, Coastal and Shelf Science, 77(2): 206-213. DOI 10.1016/j.ecss.2007.09.024.

Yin, C., Li, Y. and Urich, P. 2013. Simclim 2013 data manual. C. Ltd (Ed.). New Zealand. 